\title{
DAESH IN THE PERSPECTIVE OF VARIOUS RESEARCH SCHOOLS
}

\author{
Grzegorz KLEIN, M.A.
}

National Defence University, Warsaw, Poland

\begin{abstract}
The creation of the "Caliphate" is one of the greatest threats to international order. So, it is reasonable to attempt to determine the nature of this organisation. The various schools in the area of international relations are helpful in this regard. For this purpose, the characteristics of Daesh are shown in the first part of the article. In subsequent sections of the conclusions to the first part, the most important research schools have been compared.

According to the accepted assumption, the school of realism is the most appropriate for the study of Daesh. However, other schools can contribute to a better understanding of the organisation, showing the multidimensional and multifaceted threats for the international order coming from Daesh.
\end{abstract}

Keywords: Daesh, realism, liberalism, constructivism, Marxism, feminism

\section{Introduction}

One of the biggest current threats to international security is a terrorist organisation known as Daesh ${ }^{1}$. Its success, its progress in building a state, its ability to survive

1 This term comes from the Arabic abbreviation meaning the Islamic State in Iraq and Syria. For a significant part of the researchers' topic it is applied on a consistent basis, on the assumption that we should not create, even at a nominal level, the appearance of the "Caliphate" having nation status. 
and its range of actions makes it reasonable to attempt to diagnose the site of the organisation in terms of the international balance of power. Different schools of research developed within international relations could be helpful in this sense. It is around this issue that the main problem of this research work is focused, expressed in the question: what research school from the field of international relations explains most fully Daesh's place in the international balance of power?

An assumption points to the school of realism, as the one complying to the greatest extent with the quotas of the argument in the main research question. In order to verify the hypothesis adopted, several specific issues should be considered. The first one focuses on the most important information about Daesh. Another confronting response comes from consideration of the first problem specified by the most important schools of research in the area of international relations. In accordance with the specified problems, a division of labour in individual parts is processed.

The adopted research method is analysis of literature, combined with inductive reasoning - the nature of this reasoning results from the limited access to all data related to the functioning of the terrorist organisation. Therefore, considering the inability to make an overall judgement of the most important information related to Daesh's operations (as well as to the policy pursued in relation to this organisation by governments to combat it), the inference has a generalised nature and can shift along with the emergence of new information about Daesh. At the same time, along with the incompleteness of the research material, there is another constraint - work is set in the environment of international relations, the prospect of legal sciences is merely incidental.

\section{Daesh - current conditions}

Given Daesh's objective, which is to leave a permanent record on the map of a revived "Caliphate", it becomes reasonable to consider the current situation on the basis of the criteria taken as the base, when considering the issue of ownership of nation status. Comparing it with the idea of "statehood" proclaimed by members of Daesh will reveal the actual state of the organisation. 
1) Territory - the area covered by the rule of Daesh is not a single, coherent territory. It is rather a network of cities and towns with roads connecting them and filling the area between ownerless lands. These are a kind of security vacuum; however, it is much easier to operate in the area of Daesh than in Syria, Iraq or countries included in the coalition.

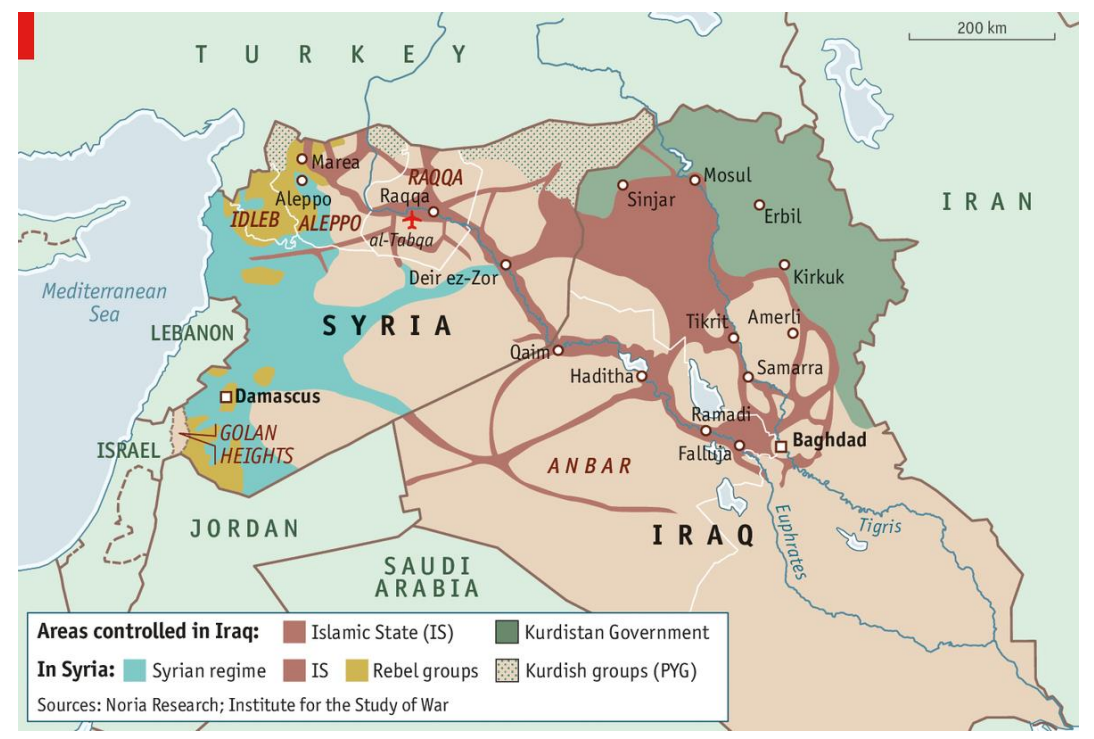

Source: The next war against global jihadism, http://www.economist.com/news/middle-eastand-africa/21617113-america-gathering-allies-long-campaign-against-extremists-iraq-and, 14.06.2016.

\section{Map 1. Daesh territory, September 2014}

An important element is the relative durability of the territory. Despite the many offensives against Daesh (some not advancing beyond plans and media speculation), the terrorists' gains are relatively stable - the core of their territory is still not under threat. This is due largely to the weakness of the coalition: countries in the region are either able to break (Syria, Iraq), or do not have sufficient capacity. Turkey is focused mainly on attacks directed against the Kurds, the US will not risk another military intervention (and, without it, the territory cannot be taken care of), the EU has no power, resources and, above all, political will. Therefore, only raids and special operations remain, thus weakening the action and not giving the possibility of victory. The balance of power could change with the intervention of Russia, but it is clear that it is "americanised" - i.e. limits its activity to raids 
and training. In addition, a coalition aimed at Daesh is also weak due to internal divisions. It is difficult to reconcile the interests of the Kurds, Turkey, Iran, the United States, Iraq and Syria (and they are not all opponents of Daesh). Thus, the territory of Daesh is still largely not threatened ${ }^{2}$.

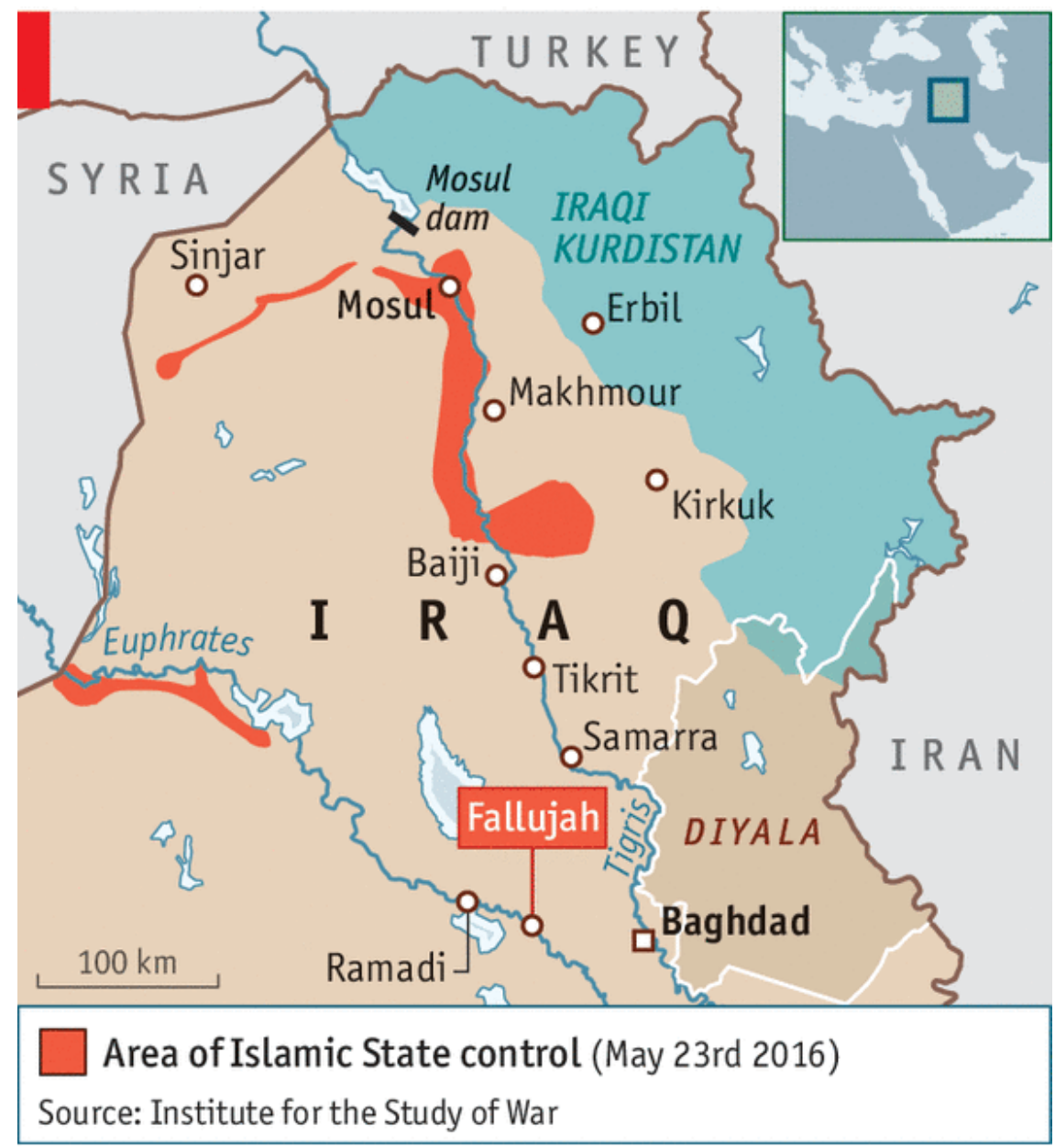

Economist.com

Source: Fallujah, again, http://www.economist.com/news/middle-east-and-africa/21699461why-retaking-jihadist-stronghold-has-become-priority-fallujah-again, 14.06.2016.

\section{Map 2. Daesh territory in Iraq, May 2016}

2 The rebound of Palmyra is - according to many indications - a one-time success. Launched at the same time, the operation of rebound of Mosul was stuck $80 \mathrm{~km}$ from the city. 
2) The power of the "Caliphate” is above all effective. On the occupied territory, terrorists have placed their respective governments in a manner that is not only absolute, but well thought out. Administration, health, education and other areas of traditional state activity function effectively. In addition, the authority is based on clever and clear criteria - designated as the Koran and Sharia.

3) The population consists not only of the victims that the media informs us of. The main inhabitants of these lands are Sunnis, and Sunni organisation refers to the „Caliphate", desired and imagined by many as accepted with joy. Especially since they felt discriminated against and humiliated by the Shiite governments of Baghdad. An example of this attitude is the behaviour of the inhabitants of Mosul - they adopted Daesh with joy, to keep in check the two-million city of terrorists suddenly needed a few thousand jihadists.

To this must be added a huge number of volunteers, pulled to the areas overrun by Daesh from around the world. They believe that the "Caliphate” awaited by the Sunni was reborn and it is their duty (which is a skilfully used propaganda tool of Daesh's) to join the "Caliphate” and fight for its survival.

4) Daesh cannot count on recognition for this, at least, at the moment, but the politics of Sunni countries in the region raise many questions. Saudi Arabia leaves the impression that it prefers Sunni Daesh to Assad in Syria, or the increase in importance of Shiites from Iran. Turkey's policy indicates that Daesh is a lesser evil for Ankara than Turkey's Kurds with their territorial claims. Therefore, while in the perspective of international law, recognition is impossible (illegal seizure of territory, the lack of respect for human rights), in the world of politics, which often does not feel constrained by international law, such a variant with its full determination cannot be ruled out ${ }^{3}$.

The above comparison of Daesh with the criteria adopted when considering the status of international actor, aspiring to the level of the state, leads to three basic conclusions: it is an organisation with a relatively stable territory, effective power and a population dedicated to the idea of the "Caliphate". All these elements are found in Daesh propaganda, aimed explicitly at building the belief that there has been a revival of the "Caliphate". $48 \%$ of their propaganda messages are focused

3 Vide G. Klein, C. Kozera, Organizacja „Państwo Islamskie” [in] „Zeszyt Problemowy TWO No. 3 (78)", Warsaw 2015. 
on political content, presenting the "Caliph" of Baghdadi as the successor and the messenger of the Prophet, who rebuilds the House for all Sunnis. This is related to the second type of message, or religious content (38\%) - which is focused on the duties of the Sunnis, and especially on the jihad as the most important of them. The last type of message is social content (14\%), showing the „Caliphate” as a place where Sunnis can fulfil their dreams and aspirations ${ }^{4}$.

In this context, it is worth mentioning three flagship products of Daesh propaganda - each of them shows the "Caliphate” as strong, capable of survival and development. The first of these is the Clanging of the Swords - a production of little more than an hour which includes interspersed elements ${ }^{5}$ of statebuilding (tearing up passports, swearing allegiance to "caliph", teaching, public demonstrations, etc.) and actualities of the fighting, including „hunting” for Iraqi soldiers (including their homes, where they are found by dressed in the uniforms of Iraqi security forces members of Daesh). It has played its role - showing to Shiites that "Caliphate" is, for them, a strong, ruthless enemy that knows no mercy. Two weeks afterwards, the surrender of Mosul had passed almost without a fight, despite the fact that Iraqi soldiers had an overwhelming advantage. But they knew, thanks to Clanging of the Swords, that they had inferior training, and if they were taken prisoner, death awaited them ${ }^{6}$.

These assumptions were confirmed a month later, after the occupation of Tikrit. In the hometown of Saddam Hussein, Daesh arrested many Iraqi soldiers (most of them were recruits). Shortly after the occupation there was a massacre, immortalised in one of the bloodiest productions of Daesh propaganda ${ }^{7}$. From 560 to 770 prisoners might have died in mass executions, although the terrorists

4 Data for the period July 2014 - August 2015, R., Zgryziewicz, Daesh Information Campaign and its influence, pp. 29-32, http://stratcomcoe.org/ [20.05.2016].

5 According to research of the author: juggling of narratives in a single production is a typical procedure in propaganda of Daesh.

6 Clanging of the Swords, Part 4, http://jihadology.net/2014/05/17/al-furqan-mediapresents-a-new-video-message-from-the-islamic-state-of-iraq-and-al-sham-clanging-ofthe-swords-part-4/ [20.05.2016].

7 New ISIS video showing battle, http://www.liveleak.com/view?i=a7f_1406610219 [20.05.2016]. And in this case there is a mixed design, the executions take the last minutes of over a half-hour production. 
have announced that they killed 1700 of them ${ }^{8}$. The last of the key productions contains only one execution. However, this was extremely brutal - burning alive. It takes a minute, but the production itself takes more than 20 minutes. This professionally assembled record shows the strength of the coalition, the confessions of a pilot and victims (mostly children) carried out from the position of Daesh'. The message has a dual nature. Firstly, it is „satisfying the needs of justice" ${ }^{10}$. Secondly, like the previous productions, it shows the strength of Daesh - a revived "Caliphate" that is able to survive, grow, conquer new lands, ensure the safety of Sunnis, and, if necessary, able to impose fair and dissuasive penalties.

\section{Daesh in the perspective of realism}

Realism for the purpose of this discussion is understood as a study to convey the true nature of things, showing an objective and natural mechanism, not subject to human will. The central value, determinant of conduct is the interest of the countries perceived in terms of power, related to everything else - including morality - which is secondary ${ }^{11}$. Therefore, international relations are conflictual in their nature, as the state's most important task, implemented on the basis of a rational evaluation, is survival and development, thus ,international policy is a policy of power, and the state focuses mainly on the purposes, the means and methods of its application"12.

Of all the analysed schools of research, it is realism that most fully describes Daesh's place in the international balance of power. This is indicated by the following:

8 Iraq: Islamic State Executions in Tikrit, https://www.hrw.org/news/2014/09/02/iraqislamic-state-executions-tikrit [20.05.2016].

9 Healing the believers' chests, http://video.foxnews.com/v/4030583977001/warningextremely-graphic-video-isis-burns-hostage-alive/?\#sp=show-clips [20.05.2016].

10 At the end of the movie, after the execution, the personal data of 10 pilots is shown, along with the information that they are "wanted dead" and is the prize designated for those who kill them.

11 H.J. Morgenthau, Politics Among Nations: The Struggle for Power and Peace, Warsaw 2010, pp. 20-30.

12 R. Szpyra, Bezpieczeństwo militarne państwa, Warsaw 2012, p. 86. 
1) Striving for their own statehood, raising the "caliphate” to the role of the most important purpose. In the paradigm of the realistic school, speaking about the fact that the most important fact - summa summarum - is the state is the only significant actor in international relations. In the interpretation of jihadists, only a "caliphate" is able to provide legitimate security to the Sunni, given the chance of survival and development, understood according to their perception of Islam.

2) Only states are able to overcome Daesh. This is a threat which no non-state power can handle. The EU is too weak, NATO - because of Turkey's policy and the weakness of European members of NATO - is unable to create a common policy and therefore carry out joint action in this area.

3) The creation, development, continued existence and eventual collapse are fully dependent on one factor - power. No action from the directory of soft power, no constructive approach, no international organisation has, in relation to this organisation, a causative power.

\section{Daesh in the perspective of liberalism}

A perception of liberalism, adopted in these considerations, implies, first of all, highlighting the importance of the role of democracy, liberalism, and cooperation between countries, which strive for cooperation and consensus and are able to avoid wars. Actually, in this view, a war is not a kind of historical necessity (as realists see it), but the result of misunderstandings, lack of rationality and poor construction of political structures ${ }^{13}$. Redemption of conflict is thus a reference to the classical liberal thinkers' school, which emphasised the value of democracy ${ }^{14}$. An essential element of it is soft power, understood as , an ability to obtain what is desired through attraction rather than using coercion or payment. It grows with the attractiveness of the country's culture, political ideals and executing policies. When our policy is seen as legally valid in the eyes of others, our soft power is intensified"15.

13 Ibidem, pp. 86-88.

14 Vide M.W. Doyle, Three Pillars of Liberal Peace, http://www.jstor.org/stable/30038953 [20.05.2016].

15 J.S. Nye Jr., Soft Power: The Means to Success in World Politics, Warsaw 2007, p. 25. 
The adoption of a realistic paradigm does not imply disregarding other research schools, which may help to explain Daesh's place in the international balance of power. Such a supporting role, among others, can be implemented by a liberal school. It emphasises the will of the people, their activity. This is evident in the case of Daesh - an organisation that was formed largely on the basis of a centuriesold dream of the rebirth of the Sunni „caliphate". Without their activity, which includes volunteers from countries of the region and around the world, the rise of Daesh would not be possible. Therefore, although this organisation is committed to its own statehood, its emergence is determined to the non-state, international activity of people. People who seem to act in the spirit, which is the crème de la crème of liberal thought, the social contract. People who feel themselves to be free (unencumbered unacceptably by the legislation of existing countries), decided to establish a state, referred to as the „Caliphate”.

\section{Daesh in the perspective of constructivism}

Constructivism is understood in this study as an approach regarding reality as a social construction, thus „relations between individuals, groups, communities and countries consisting essentially of thoughts and considerations, either motivational or ideological, never in relation to the nature of the material. Existing material forms of social agreements are merely contractual, relative constructs"16.

Without proper motivation to create a new, strong entity in the international balance of power, and without ideology, which in the case of Daesh has crucial importance, the rise of this organisation would not be possible. It was created precisely because of the specific socio-political thought, based on the foundation of religion. It can, therefore, be considered as a social construct.

16 R. Szpyra, op. cit., p. 89. 


\section{Daesh in the perspective of Marxism}

Within the classical frame of Marxism, adopted for the purposes of this discussion, it is assumed that the state is a historical phenomenon, in which the key elements are divisions by classes, the interests of these classes and how their security in this concept, the state is understood as an institution for the protection of the interests of the ruling class, with the help of the law. Therefore, the law is understood as the will of the ruling class ${ }^{17}$.

The Marxism theory of the creation of the state is inextricably linked to the distribution of the means of production. Before the rise of Daesh, the Sunni had repeatedly been victims in this respect. This happened in northern Iraq (as a result of the policy of the Shiite government in Baghdad), in Syria under Assad, and finally in Western countries, where Muslims (as Sunnis and Shiites) feel like second-class citizens. To break out of this humiliation ${ }^{18}$ and defeat the ruling class (the Shiites, Assad, the Western world), they decided to make a revolutionary change in social relations, thus acting in the spirit of the Marxist paradigm.

See also the similarity, at thelevel of willingness, to recognise historicaldeterminism, which is subjected to the whole world, and which would bring universal peace and prosperity. Worldwide happiness is to be provided, in this case, not by inevitable class struggle, but religion. The starting points are, therefore, different, but the global aspirations are the same.

\section{Daesh in the perspective of feminism}

In this discussion, feminism can be used to bring a feminist perspective paradigm, which is a struggle for women's rights ${ }^{19}$. This struggle results from the necessity to comply with justice, because human nature is both masculine and feminine.

17 Marksizm-leninizm [in] „Leksykon politologii”, under ed. A. Antoszewski, R. Herbut, Wroclaw 1999, pp. 294-296.

18 Vide D. Moisi, Geopolitics of Emotion, Warsaw 2012.

19 Feminizm [in] "Leksykon ..., p. 135. 
This equal approach is reflected in the perception of international reality, which should cast the force (which is the result of male domination) for partnership, cooperation and support the activities undertaken by morality ${ }^{20}$.

It seems useless to search for any links between Daesh and a mainstream feminist. However, it is worth noting that of all the participants associated with what is going on in Syria and Iraq, Daesh seems to be almost the only one that has a "deal" for women. The member states of the Coalition against the terrorists do not seem to generally acknowledge women's issues. Meanwhile, Daesh, acting in a spirit of equality, prepared its message not only for men but also for women. This is proved by numerous publications, emphasising that the presence of women is essential for the "Caliphate", because they have to play important social roles, including on the battlefield ${ }^{21}$. Of course, this role is distant from what mainstream feminism understands as equality. However, the role of women is largely appreciated, which seems to explain the numerous cases of female volunteers joining Daesh.

\section{Conclusions}

The accepted hypothesis was a result of the research confirmed. Of all the relevant research schools of international relations, it is realism that most fully allows us to determine the place of Daesh in the international balance of power.

However, each of the other theories contributes to increasing our knowledge about Daesh. Liberalism points to the mobility and the willingness of the people that make up their organisation, regardless of the will of states; constructivism reveals the idea that lies at the root of such behaviour, like Marxism, showing that the socio-economic issues considered from the point of view of the distribution of capital and means of production play an important role in the case of Daesh. Even feminism, to some extent, enriches our knowledge, allowing us to understand why so many young women decide to join Daesh.

20 Vide J.A. Tickner, Hans Morgenthau's Principles of Political Realism: A Feminist Reformulation, http://mil.sagepub.com/content/17/3/429 [20.05.2016].

21 Vide A Sister's Role in Jihad, https://archive.org/details/SistersRoleInJihad [20.05.2016]. 
This leads to another conclusion, indicating the necessity for further research, not only dedicated to Daesh, but also focused on developing the theoretical potential of international relations. It is clear that the prospect of 0-1 for the research schools (ergo approach, according to which only one school can holistically describe the reality of international standard), may be unreliable. Daesh is in its nature a phenomenon which is best located in the area of realistic theory, but with essential elements important in the perception of other research schools. This should lead to further discussion of the theories and research, especially in the case of universities playing a leading role in the study of international security.

This idea becomes stronger, when the belief in the permanence of the „Caliphate” and the threats coming from it is stronger. Although Daesh is the object of continuous attacks, and some of them appear to be well prepared and able to harm the terrorists, this organisation has shown a great ability to survive. It may therefore become an important element of the contemporary international order.

\section{Bibliography}

A Sister's Role in Jihad, https://archive.org/details/SistersRoleInJihad.

Clanging of the Swords, Part 4. http://jihadology.net/2014/05/17/al-furqan-mediapresents-a-new-video-message-from-the-islamic-state-of-iraq-and-al-shamclanging-of-the-swords-part- $4 /$.

Doyle M. W., Three Pillars of the Liberal Peace, http://www.jstor.org/stable/30038953.

Fallujah, again, http://www.economist.com/news/middle-east-and-africa/21699461why-retaking-jihadist-stronghold-has-become-priority-fallujah-again.

Healing the believers' chests. http://video.foxnews.com/v/4030583977001/warningextremely-graphic-video-isis-burns-hostage-alive/?\#sp=show-clips.

Iraq: Islamic State Executions in Tikrit, https://www.hrw.org/news/2014/09/02/iraqislamic-state-executions-tikrit.

Klein G., Kozera C., Organizacja „Państwo Islamskie” [in] „Zeszyt Problemowy TWO No. 3 (78)", Warsaw 2015.

Leksykon politologii, under ed. Antoszewski A., Herbut R., Wrocław 1999.

Moisi D., Geopolitics of Emotion, Warsaw 2012.

Morgenthau H. J., Politics Among Nations: The Struggle for Power and Peace, Warsaw 2010.

New ISIS video showing battle, http://www.liveleak.com/view?i=a7f_1406610219. 
Nye J.S. Jr., Soft Power: The Means to Success in World Politics, Warsaw 2007.

Szpyra R., Bezpieczeństwo militarne państwa, Warsaw 2012.

Tickner J.A., Hans Morgenthau's Principles of Political Realism: A Feminist Reformulation, http://mil.sagepub.com/content/17/3/429.

The next war against global jihadism, http://www.economist.com/news/middle-east-andafrica/21617113-america-gathering-allies-long-campaign-against-extremists-iraqand.

Zgryziewicz R., Daesh Information Campaign and its influence, http://stratcomcoe.org/. 